\title{
Agronomic and $P$ recovery efficiency of organomineral phosphate fertilizer from poultry litter in sandy and clayey soils
}

\author{
Jerusa Maia e Sá(1), Cláudia Pozzi Jantalia(2), Paulo César Teixeira(3), José Carlos Polidoro(3), \\ Vinícius de Melo Benites ${ }^{(3)}$ and Adelson Paulo Araújo ${ }^{(1)}$
}

(1)Universidade Federal Rural do Rio de Janeiro, Departamento de Solos, BR-465, Km 47, CEP 23890-000 Seropédica, RJ, Brazil. E-mail:
jerusamaiasa@yahoo.com.br, aparaujo@ufrrj.br ${ }^{(2)}$ Embrapa Agrobiologia, BR-465, Km 7, Ecologia, Caixa Postal 74.505, CEP 23891-000
Seropédica, RJ, Brazil. E-mail: claudia.jantalia@embrapa.br ${ }^{(3)}$ Embrapa Solos, Rua Jardim Botânico, no 1.024, Jardim Botânico,
CEP 22460-000 Rio de Janeiro, RJ, Brazil. E-mail: paulo.c.teixeira@embrapa.br, jose.polidoro@embrapa.br, vinicius.benites@embrapa.br

Abstract - The objective of this work was to evaluate agronomic and $\mathrm{P}$ recovery efficiencies of a granulated organomineral phosphate fertilizer (OMF) produced from poultry litter, compared with those of monoammonium phosphate (MAP), in soils with different textures. The experiment followed a $2 \times 2 \times 4+2$ factorial arrangement, with two Oxisols (sandy loam and clay loam textures), two sources of $\mathrm{P}$ (OMF and MAP), four levels of $\mathrm{P}\left(50,100,200\right.$, and $\left.400 \mathrm{mg} \mathrm{kg}^{-1}\right)$, besides two control treatments without $\mathrm{P}$ application. The treatments were evaluated in 10-kg pots filled with soil, during four successive cultivations of corn without replacing the $\mathrm{P}$ absorbed by the plants, in order to evaluate the actual and residual effects of the fertilizers. Available P contents in the soil were higher with the MAP fertilizer in the sandy loam soil, with no significant differences between fertilizers in the clay loam soil. OMF had a greater immediate effect and promoted a higher dry matter yield in the first cultivation; however, the residual effects of the fertilizers did not differ in the other cultivations. P accumulation by plants was not affected by the fertilizer used. OMF had higher agronomic efficiency, but $\mathrm{P}$ recovery efficiency did not differ significantly between fertilizers. OMF performance indicates good potential use of poultry litter as fertilizer, in organomineral formulations.

Index terms: Zea mays, biomass accumulation, phosphate fertilization, P recovery efficiency, tropical soils.

\section{Eficiência agronômica e de recuperação de $P$ de fertilizante fosfatado organomineral granulado produzido com cama de frango em solo arenoso e argiloso}

Resumo - O objetivo deste trabalho foi avaliar as eficiências agronômica e de recuperação de $\mathrm{P}$ de fertilizante fosfatado organomineral (FOM) granulado, produzido com cama de frango, comparadas às do monoamônio fosfato (MAP), em solos com diferentes texturas. $\mathrm{O}$ experimento seguiu um arranjo fatorial $2 \times 2 \times 4+2$, com dois Latossolos (texturas areia franca e franco argilosa), duas fontes de P (FOM e MAP), quatro doses de P (50, 100,200 e $400 \mathrm{mg} \mathrm{kg}^{-1}$ ), além de dois controles sem aplicação de P. Os tratamentos foram avaliados em vasos com $10 \mathrm{~kg}$ de solo, durante quatro cultivos sucessivos de milho sem reposição do $\mathrm{P}$ absorvido pelas plantas, para permitir as avaliações de efeito imediato e residual dos fertilizantes. Os teores de P assimilável no solo foram maiores com o MAP, no solo areia franca, sem diferenças significativas entre fertilizantes no solo franco argiloso. O FOM teve maior efeito imediato e promoveu maior produção de matéria seca no primeiro cultivo; no entanto, o efeito residual dos fertilizantes não diferiu nos demais cultivos. $\mathrm{O}$ acúmulo de $\mathrm{P}$ pelas plantas não foi influenciado pelo fertilizante utilizado. O FOM apresentou maior eficiência agronômica, mas a eficiência de recuperação de $\mathrm{P}$ não diferiu significativamente entre os fertilizantes. O desempenho do FOM indica bom potencial de uso da cama de frango como fertilizante, em formulações organominerais.

Termos para indexação: Zea mays, acúmulo de biomassa, adubação fosfatada, eficiência de recuperação de P, solos tropicais.

Introduction

Phosphorus deficiency in tropical soils is an important limiting factor for the favorable development of crops (Santos et al., 2011). In most cases, the efficiency of phosphate fertilization is very low (Kochian, 2012) because of the chemical, physical, and mineralogical characteristics of the soil and of the solubility, composition, and physical structure of the fertilizer (Hansel et al., 2014). 
Phosphate rocks used as raw material for the production of phosphate fertilizers are a nonrenewable natural resource (Vaccari, 2009). Therefore, new sources of $\mathrm{P}$ should be evaluated in agronomic, environmental, and economic perspectives to complement or even replace the use of conventional fertilizers in agriculture (Cordell et al., 2009).

Brazil is the second largest producer of poultry meat in the world, with an annual slaughter of approximately 5.7 billion chickens (IBGE, 2016) and an estimated production of 16 million tons of poultry litter (Schneider et al., 2012). Waste from animal production is widely appplied as organic fertilizer, and the use of waste in the formulation of organomineral fertilizers (OMFs) has increased in recent years (Morais \& Gatiboni, 2015). The Brazilian policy on solid waste, "Política Nacional de Resíduos Sólidos" (Brasil, 2010), recommends recycling or reusing waste to reduce the amount generated, stimulating the OMF market. Furthermore, the diversity of available organic sources and the feasibility of adding value to agricultural residues with OMF favor the diversification and decentralization of fertilizer production in the country (Benites et al., 2010).

Compared with soluble mineral fertilizers, OMFs are less reactive in the soil but may have greater agronomic efficiency because their gradual solubilization allows the release of nutrients during crop development (Kiehl, 2008). Moreover, the promotion of soil microbiological activity by the addition of the organic residues present in OMF formulations may stimulate crop development (Rodrigues et al., 2011). Another advantage of OMFs is the increased bioavailability of $\mathrm{P}$ due to competition for $\mathrm{P}$ adsorption sites by the organic acids generated by the mineralization of the organic matter added to the soil (Fernandes et al., 2015). However, this last aspect needs to be better studied by evaluating different mineral sources of $\mathrm{P}$ in soils of different textural classes.

The objective of this work was to evaluate agronomic and $P$ recovery efficiencies of a granulated organomineral phosphate fertilizer (OMF) produced from poultry litter, compared with those of monoammonium phosphate (MAP), in soils with different textures.

\section{Materials and Methods}

The experiment was conducted in a greenhouse at Embrapa Agrobiologia, in the municipality of Seropédica, RJ, Brazil. A $2 \times 2 \times 4+2$ factorial arrangement was adopted, with two Oxisols (sandy loam and clay loam textures), two sources of $\mathrm{P}$ (OMF and MAP), four concentrations of $\mathrm{P}(50,100,200$, and $400 \mathrm{mg} \mathrm{kg}^{-1}$ ), and two control treatments without $\mathrm{P}$ application (one for each type of soil), in a randomized complete block design with five replicates.

Each experimental unit consisted of corn (Zea mays L.) plants grown in a pot filled with $10 \mathrm{~kg}$ of soil. Four successive cultivations were assessed without the replacement of the $\mathrm{P}$ absorbed by the plants, in order to exhaust extractable forms of the element in the soil. This was done to allow evaluating the immediate and residual effects of the tested fertilizers. The BRS 1060 hybrid was used, and four plants were maintained in each pot after thinning.

Two Latossolos Vermelho-Amarelos (Santos et al., 2013), i.e., Typic Hapludoxes, were tested, one of sandy loam texture (100 $\mathrm{g} \mathrm{kg}^{-1}$ clay), from the municipality of Luis Eduardo Magalhães, in the state of Bahia, and one of clay loam texture ( $380 \mathrm{~g} \mathrm{~kg}^{-1}$ clay), from the municipality of Paula Cândido, in the state of Minas Gerais, Brazil. Both soil types were collected at a depth of $0.0-0.20 \mathrm{~m}$. Table 1 shows the chemical properties of the soils, determined according to Claessen (1997).

Two fertilizers were evaluated: pure MAP $(56 \%$ $\mathrm{P}_{2} \mathrm{O}_{5}$ ), formulated as powder, and granulated OMF $\left(23 \% \mathrm{P}_{2} \mathrm{O}_{5}\right)$. The OMF was composed of a mixture of $60 \%$ poultry litter, $38 \%$ MAP pure for analysis (PA), and $2 \%$ potassium silicate. The proportion of each component in the OMF was determined by Embrapa Solos. The poultry litter was obtained from a commercial poultry farm located in the municipality of Nova Friburgo, in the state of Rio de Janeiro, and this material was ground and sieved using a mesh of $0.025 \mathrm{~mm}$ (500 mesh). The mineral fertilizer and poultry litter were homogenized in a V-type mixer and sieved again using the same mesh. Granules were obtained by placing the mixture in a disk pelletizer and gradually adding water using a spray bottle. Granules with a diameter of $2-4 \mathrm{~mm}$ were used. The fertilizer was oven-dried, at $40^{\circ} \mathrm{C}$, with forced-air circulation.

Soil clods were crushed and sieved using a $4-\mathrm{mm}$ mesh, and the acidity was corrected in both soils, respectively, with 3.5 and $2.8 \mathrm{Mg} \mathrm{ha}^{-1}$ dolomitic limestone, with $85 \%$ total relative neutralizing power. Each pot was separately incubated with limestone for 30 days, and moisture was maintained at $80 \%$ field 
capacity. After incubation with limestone, phosphate fertilizers were applied and incorporated into the whole volume of the soil, in each experimental unit. The other nutrients were added in the form of a solution, at the doses of 150 and $50 \mathrm{mg} \mathrm{kg}^{-1} \mathrm{~K}$ (as potassium nitrate) and 11.2 and $19.9 \mathrm{mg} \mathrm{kg}^{-1} \mathrm{~S}$ (as ammonium sulfate), for the sandy loam and clay loam soils, respectively. The $\mathrm{N}$ dose for both soil types was $100 \mathrm{mg} \mathrm{kg}^{-1}$, with 46.2 and $82.1 \mathrm{mg} \mathrm{kg}^{-1} \mathrm{~N}$ as ammonium sulfate and 53.8 and $17.9 \mathrm{mg} \mathrm{kg}^{-1}$ as potassium nitrate, respectively. Furthermore, $2 \mathrm{mg} \mathrm{kg}^{-1} \mathrm{Cu}\left(\mathrm{CuSO}_{4}\right), 1 \mathrm{mg} \mathrm{kg}^{-1} \mathrm{Zn}$ $\left(\mathrm{ZnSO}_{4}\right), 0.05 \mathrm{mg} \mathrm{kg}^{-1} \mathrm{~B}$ (borax), and $0.2 \mathrm{mg} \mathrm{kg}^{-1} \mathrm{Mo}$ (sodium molybdate) were added to both soil types. Maintenance fertilization was performed with $\mathrm{N}$, $\mathrm{K}$, and $\mathrm{S}$, before the second and third cultivations of corn, using the same doses as those applied in the first cultivation.

The four successive corn cultivations were carried out in June/August 2014, September/October 2014, July/August 2015, and August/October 2015. Plants were harvested at 50, 24, 41, and 43 days after plant emergence in the first, second, third, and fourth cultivations, respectively. At harvest, plants were cut close to the soil. The soil was sieved to separate the roots, which were washed in a sieve under running water. The aerial part and roots were dried in an oven with forced-air circulation, at $60^{\circ} \mathrm{C}$, until reaching constant mass, and then weighed and ground. The $\mathrm{P}$ content was determined by nitric-perchloric digestion and colorimetry (Malavolta et al., 1997). The accumulation of $\mathrm{P}$ in each plant portion was obtained as the product of the concentration of $\mathrm{P}$ and the mass of dry matter produced. For each cultivation, approximately $30 \mathrm{~g}$ of soil were collected from each pot to determine the amount of available P, using a Mehlich-1 extractor (Claessen, 1997).

The agronomic efficiency [(production of dry matter with $\mathrm{P}$ - production of dry matter without $\mathrm{P}$ )/amount of $\mathrm{P}$ applied] and $\mathrm{P}$ recovery efficiency of the fertilizer $[(\mathrm{P}$ accumulated with $\mathrm{P}-\mathrm{P}$ accumulated without $\mathrm{P}) /$ amount of $\mathrm{P}$ applied] were calculated according to Fageria et al. (2003) in each experimental unit.

Data and values accumulated in the four cultivations were subjected to one-way analysis of variance, in a randomized complete block design, in a $2 \times 2 \times 4$ triple factorial arrangement, corresponding to the type of soil, source of $\mathrm{P}$, and dose of $\mathrm{P}$, excluding data from pots with control treatments. The bioavailability of $\mathrm{P}$ was determined using the two $\mathrm{P}$ sources evaluated under different conditions of $\mathrm{P}$ adsorption (soil textures). Data were adjusted to linear or quadratic regression models, considering the $\mathrm{P}$ dose as an independent variable and including data from pots with control treatments. The least significant difference was estimated between treatments using Duncan's test, at $5 \%$ probability.

\section{Results and Discussion}

After the first cultivation, the amount of available $\mathrm{P}$ in the soil linearly increased as a function of the increased dose of $\mathrm{P}$ applied to both soil types, regardless of the source of $\mathrm{P}$ used (Figure 1), agreeing with Lana et al. (2014). The amount of available P in the soil for each cultivation of corn was higher in the sandy loam soil, for the two evaluated fertilizers (Figure 2). In the clay loam soil, the source of P did not affect the amount of available P; however, in the sandy loam soil, the amount of available $\mathrm{P}$ was higher with MAP. The high solubility of MAP, associated with the lower adsorption potential of the soil, resulted in a higher availability of $\mathrm{P}$ already in the first cultivation. This difference was not observed in the clay loam soil due to the higher clay content and higher adsorption potential (Chien et al., 2011).

Ferreira (2014) found higher available P contents in a Latossolo Vermelho distroférrico (clay loam dystrophic Oxisol) and in a Neossolo Quartzarênico distrófico (sandy loam Psament) when corn plants were fertilized with soluble phosphates (granulated MAP and triple superphosphate, as well as MAP diluted in water), instead of OMF (poultry litter plus granular

Table 1. Chemical properties of the two Oxisols used as substrates.

\begin{tabular}{|c|c|c|c|c|c|c|c|c|c|c|c|c|c|}
\hline \multirow[t]{2}{*}{ Soil } & \multicolumn{2}{|c|}{$\mathrm{pH}$} & $\mathrm{P}$ & $\mathrm{K}$ & $\mathrm{S}$ & $\mathrm{Ca}$ & $\mathrm{Mg}$ & Al & $\mathrm{H}+\mathrm{Al}$ & SB & $\mathrm{CEC}$ & \multirow{2}{*}{$\begin{array}{l}\text { BS } \\
(\%)\end{array}$} & \multirow{2}{*}{$\begin{array}{c}\text { Organic C } \\
\left(\mathrm{g} \mathrm{kg}^{-1}\right)\end{array}$} \\
\hline & $\mathrm{H}_{2} \mathrm{O}$ & $\mathrm{CaCl}_{2}$ & \multicolumn{3}{|c|}{------ $\left(\mathrm{mg} \mathrm{dm}^{-3}\right)------$} & $--\cdot$ & 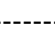 & $-(\mathrm{cmc}$ & $\left.m^{-3}\right)-$ & & -- & & \\
\hline Sandy loam texture & 5.0 & 3.0 & 1.2 & 8 & 5.3 & 0.1 & 0.1 & 0.3 & 1.6 & 0.2 & 1.8 & 12 & 7.2 \\
\hline Clay loam texture & 4.9 & 3.7 & 1.5 & 102 & 3.2 & 0.6 & 0.5 & 0.5 & 5.2 & 1.3 & 6.6 & 20 & 20.8 \\
\hline
\end{tabular}

Pesq. agropec. bras., Brasília, v.52, n.9, p.786-793, set. 2017 
phosphorite and pig waste plus MAP in fluid form). According to the author, the release of $\mathrm{P}$ was faster with soluble sources because the availability of the organic fraction of the element in the soil requires the mineralization of organic matter. Morais \& Gatiboni (2015) did not find significant differences in available $\mathrm{P}$ between soluble sources of $\mathrm{P}$ and OMF from poultry litter, at a depth of up to $2.5 \mathrm{~cm}$, in columns filled with a Nitossolo (Alfisol) and incubated for 32 days.

In the first cultivation, the OMF provided greater accumulation of dry matter in corn plants than MAP did, in the two analyzed soils (Figure 3). With OMF, the addition of $\mathrm{P}$ to the soil may have promoted an increase in soil microbial biomass (Gatiboni et al., 2008), consequently increasing the availability of the other nutrients present in poultry litter, which might have favored the accumulation of dry matter in the first cultivation. Similarly, Morais \& Gatiboni (2015) also reported an increase in the microbial biomass of a Nitossolo (Alfisol) (411 $\mathrm{g} \mathrm{kg}^{-1}$ clay) fertilized with

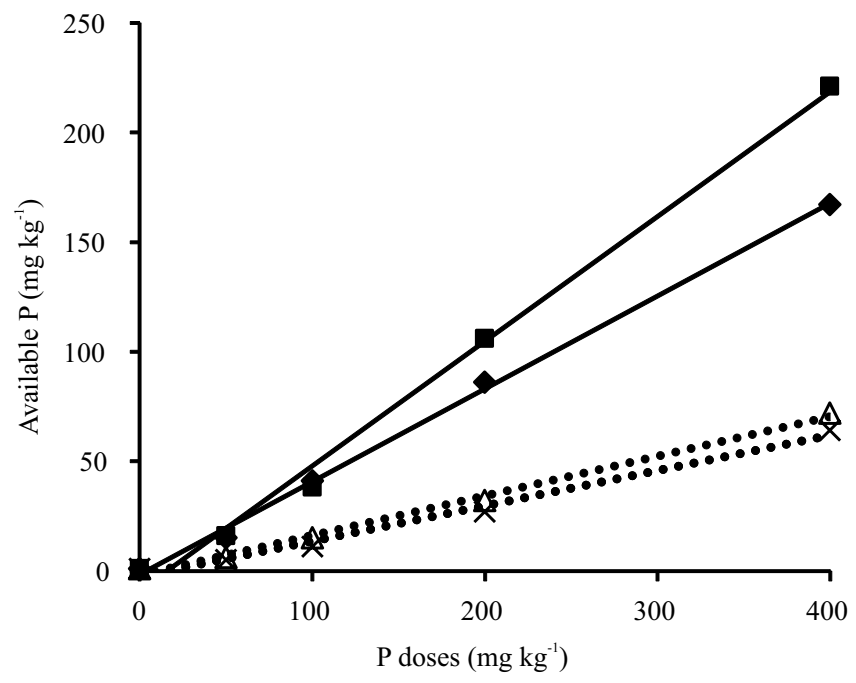

$\longrightarrow$ - Sandy loam with OMF $\quad---\Delta$-- Clay loam with OMF $\longrightarrow$ - Sandy loam with MAP

Figure 1. Available $\mathrm{P}$ content in the soil (Mehlich-1 extractor) in function of four $\mathrm{P}$ doses, as organomineral phosphate fertilizer (OMF) or monoammonium phosphate (MAP), applied to corn (Zea mays) plants grown in pots filled with sandy loam and clay loam Oxisols, in the first cultivation. Regression equations: OMF in the sandy loam soil, $y=1.525$ $+0.4235 x$; MAP in the sandy loam soil, $y=-8.95+0.569 x$; OMF in the clay loam soil, $y=-1.95+0.181 x$; and MAP in the clay loam soil, $y=-2.625+0.1615 x$. All coefficients of determination of the models were above 0.98 . mineral and organomineral phosphate sources from poultry litter.

In the third cultivation, a significant effect was verified only for the texture classes, with increased dry matter production in the sandy loam soil (Figure 3). Treatments did not differ significantly in the second and fourth cultivations.

There was no significant difference between the evaluated fertilizers regarding the accumulation of $\mathrm{P}$ in corn plants. However, significant differences were observed between the soils, and higher values were obtained for the sandy loam soil in all cultivations, except in the fourth one (Figure 3). Silva et al. (2012) did not find differences in the biomass accumulation of Urochloa decumbens in a Latossolo Vermelho distrófico (Rhodic Haplustox) (165 $\mathrm{g} \mathrm{kg}^{-1}$ clay) fertilized with organic, organomineral, and soluble mineral fertilizers, 35 days after planting. However, according to the authors, the accumulation of $\mathrm{P}$ was higher when the soluble mineral fertilizer was used.

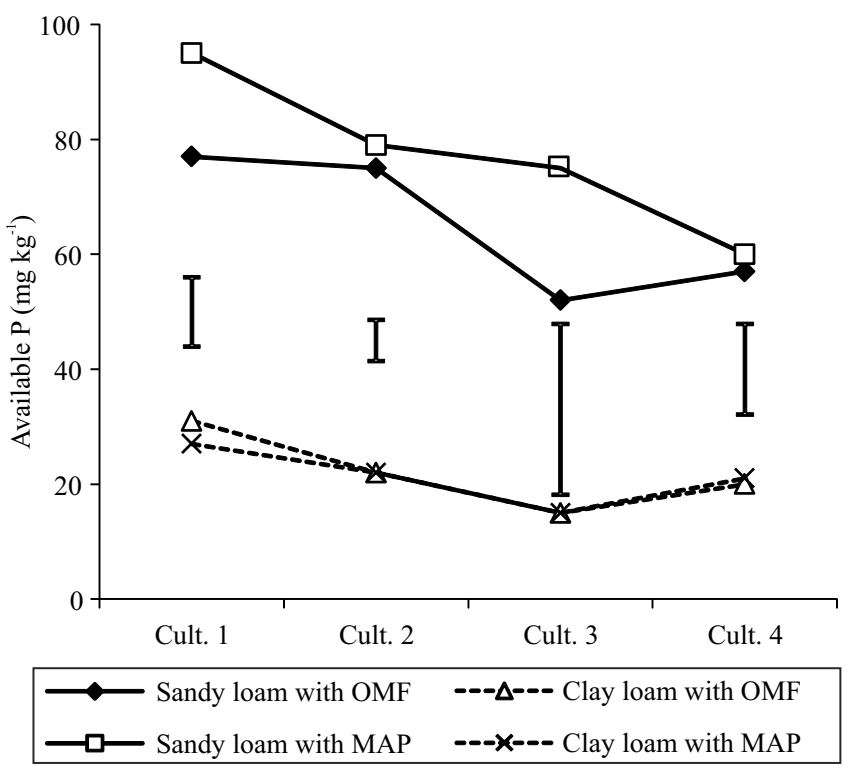

Figure 2. Available $\mathrm{P}$ content in the soil (Mehlich-1 extractor) in function of four $\mathrm{P}$ doses, as organomineral phosphate fertilizer (OMF) or monoammonium phosphate (MAP), applied to corn (Zea mays) plants grown in pots filled with sandy loam and clay loam Oxisols, in successive cultivations. Values represent the mean of the four doses of $\mathrm{P}$ applied to the soil, and vertical bars represent the least significant difference estimated by Duncan's test, at 5\% probability. 
The addition of organic matter to the soil via OMF may increase the residual effect of phosphate fertilization through the gradual release of the nutrient into the soil (Kiehl, 2008) and through the competition between the released organic acids and phosphate ions for adsorption sites on the mineral colloids of the soils (Fernandes et al., 2015). However, this hypothesis was not confirmed in the present study because the
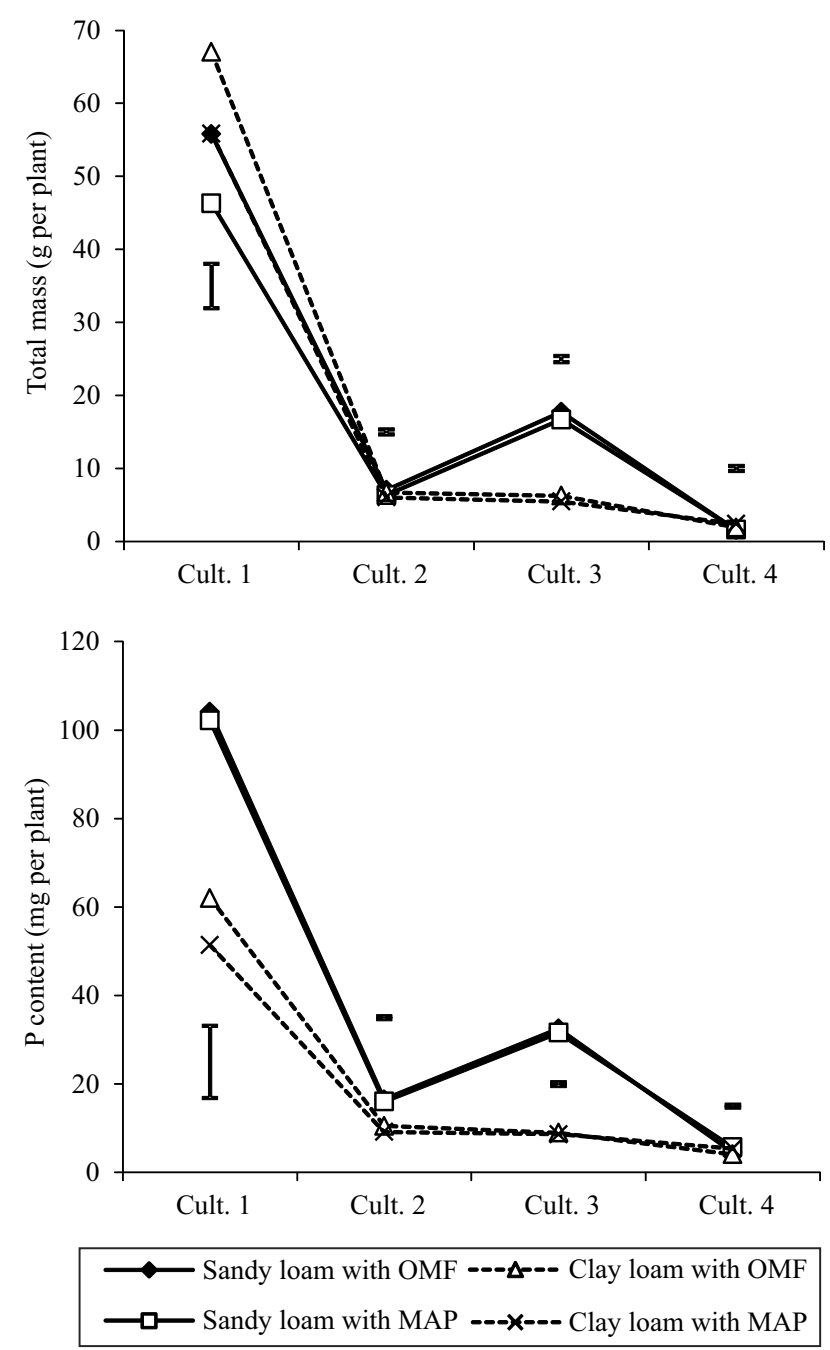

Figure 3. Accumulation of dry matter and phosphorus in the aerial part and roots of corn (Zea mays) plants after four successive cultivations in pots filled with sandy loam and clay loam Oxisols, in function of the application of four doses of $\mathrm{P}$ as organomineral phosphate fertilizer (OMF) or monoammonium phosphate (MAP). Values represent the mean of the four doses of $\mathrm{P}$ applied to the soil, and vertical bars represent the least significant difference estimated by Duncan's test, at $5 \%$ probability. production of dry matter was higher with OMF only in the first cultivation; therefore, the use of this P source did not allow a greater residual effect of phosphate fertilization in subsequent harvests (Figure 3). The amount of organic waste added by the OMF may have been too small to increase organic matter content and allow a greater residual effect due to fertilization (Morais \& Gatiboni, 2015).

The decreased accumulation of dry matter and $\mathrm{P}$ by corn plants in the different cultivations (Figure 3) can be attributed to the lower content of available $\mathrm{P}$, due to the extraction of successive cultivations and also to the soil inversion after each cultivation, which would have intensified nutrient adsorption in the mineral fraction of the soil (Scivittaro et al., 1997).

The accumulation of dry matter in the four cultivations responded to the applied doses of $\mathrm{P}$ according to a quadratic model, in both soils and with both sources of $\mathrm{P}$ evaluated (Figure 4). The doses of $\mathrm{P}$ for maximum accumulation of dry matter were estimated at 275 and $252 \mathrm{mg} \mathrm{kg}^{-1}$ for OMF and MAP, respectively, in the sandy loam soil, and at 313 and $322 \mathrm{mg} \mathrm{kg}^{-1}$, in the clay loam soil. Therefore, plants responded to higher doses of $\mathrm{P}$ in the clay loam soil, whereas the accumulation of dry matter by plants decreased with higher doses of $\mathrm{P}$ in the sandy loam soil. The doses of $\mathrm{P}$ for maximum accumulation of dry matter were 109 and $97 \mathrm{~g}$ per plant, respectively for fertilization with OMF and MAP, in the sandy loam soil, and 112 and $99 \mathrm{~g}$ per plant, in the clay loam soil.

The accumulation of $\mathrm{P}$ by the corn plants responded linearly to the doses used, except in the sandy loam soil fertilized with MAP, in which the response was quadratic (Figure 4). The highest accumulation of $\mathrm{P}$ occurred in the sandy loam soil, due to the strong association of this variable with the content of available P (Rosolem et al., 1994), which was greater in this soil (Figures 1 and 2) due to its lower capacity for $\mathrm{P}$ adsorption. Dry matter accumulation depends on other factors, including the supply of other nutrients, temperature, and water availability (Scivittaro et al., 1997).

The agronomic efficiency of $\mathrm{OMF}$ as a $\mathrm{P}$ source was considerably higher than that of MAP due to the higher production of dry matter and the lower accumulation of $\mathrm{P}$ by fertilized corn plants, regardless of the evaluated soil type (Table 2). Similar results were observed by Bhattacharyya et al. (2008) when 
comparing a mixture of mineral and organic fertilizers with a soluble mineral fertilizer.

Differences were expected in the recovery efficiency of $\mathrm{P}$ because of the different formulations of the analyzed fertilizers (granular OMF or powder MAP), considering that their distinct contact surfaces could affect nutrient bioavailability to plants (Hansel et al., 2014). However, the recovery efficiency of the fertilizers did not differ significantly (Table 2).

The greater dry matter production by the corn plants in the first cultivation, and the absence of a significant difference in this variable in the other cultivations, show that the OMF is a promising P source for crops. The possibility of granulating poultry litter with
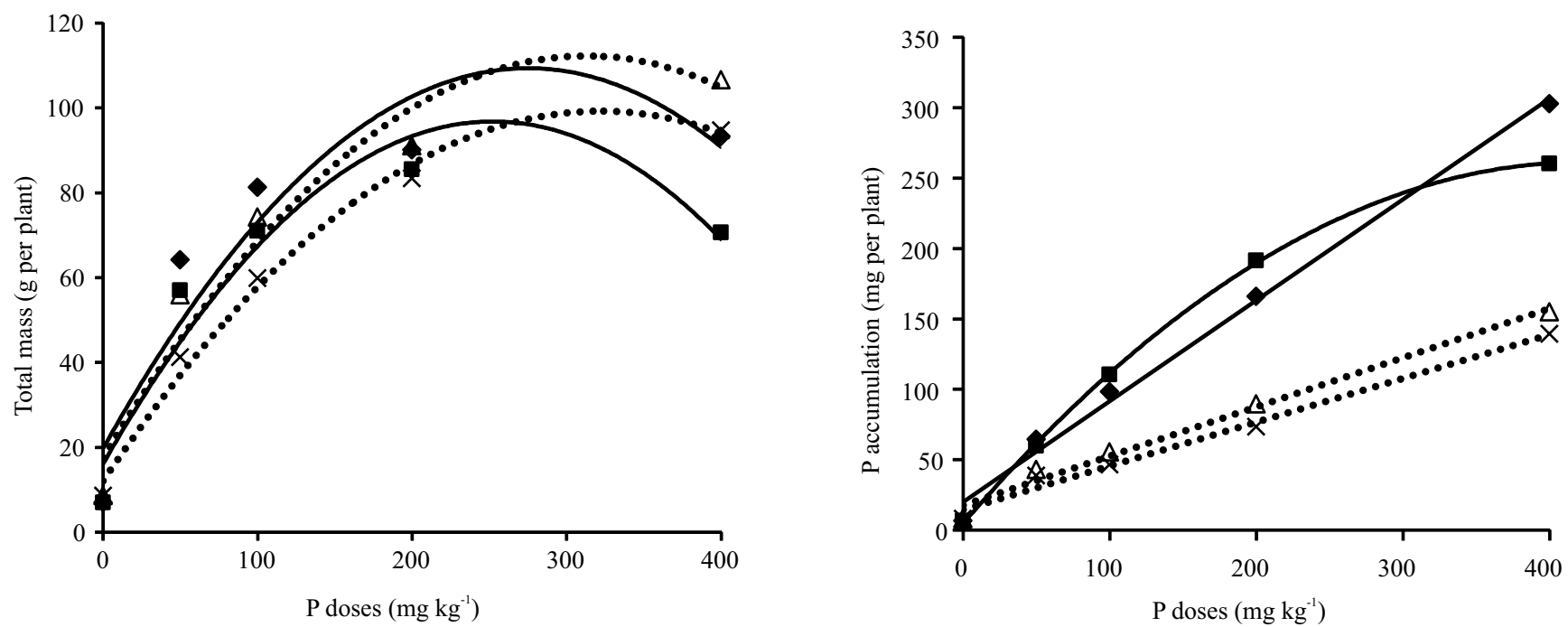

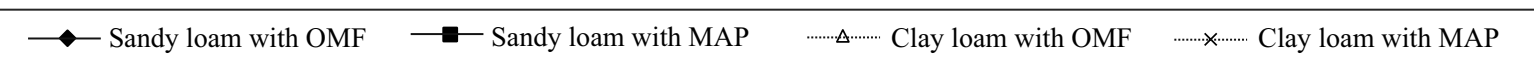

Figure 4. Accumulation of dry matter and phosphorus in the aerial part and roots of corn (Zea mays) plants after four successive cultivations in pots filled with sandy loam and clay loam Oxisols, in function of the application of four doses of $\mathrm{P}$ as organomineral phosphate fertilizer (OMF) or monoammonium phosphate (MAP). Curves represent the first or second degree models adjusted to the experimental means for accumulation of dry matter: OMF in the sandy loam soil, $\mathrm{y}=19.78151+0.65155 \mathrm{x}-0.00119 \mathrm{x}^{2} ;$ MAP in the sandy loam soil, $\mathrm{y}=16.1902+0.63945 \mathrm{x}-0.00127 \mathrm{x}^{2} ;$ OMF in the clay loam soil, $\mathrm{y}=17.63074+0.60532-0.00097 \mathrm{x}^{2}$; and MAP in the clay loam soil, $\mathrm{y}=12.10428+0.5415 \mathrm{x}-0.00084 \mathrm{x}^{2}$. Accumulation of $\mathrm{P}$ : OMF in the sandy loam soil, $y=19.9615+0.71679 x ;$ MAP in the sandy loam soil, $y=4.67046+1.2106 x-0.00143 x^{2}$; OMF in the clay loam soil, $y=17.6235+0.34971 x$; and MAP in the clay loam soil, $y=14.4605+0.31133 x$. All coefficients of determination were $>0.85$ for dry matter and 0.93 for $\mathrm{P}$ content.

Table 2. Agronomic and recovery efficiencies of four $\mathrm{P}$ doses, as organomineral fertilizer (OMF) and monoammonium phosphate (MAP), applied to corn (Zea mays) plants grown in pots with sandy loam and clay loam Oxisols ${ }^{(1)}$.

\begin{tabular}{|c|c|c|c|c|c|c|c|c|}
\hline \multirow{3}{*}{$\begin{array}{l}\mathrm{P} \text { doses } \\
\left(\mathrm{mg} \mathrm{kg}^{-1}\right)\end{array}$} & \multicolumn{4}{|c|}{ Agronomic efficiency $\left(\mathrm{g} \mathrm{mg}^{-1}\right)$} & \multicolumn{4}{|c|}{ Recovery efficiency $\left(\mathrm{g} \mathrm{g}^{-1}\right)$} \\
\hline & \multicolumn{2}{|c|}{ Sandy loam } & \multicolumn{2}{|c|}{ Clay loam } & \multicolumn{2}{|c|}{ Sandy loam } & \multicolumn{2}{|c|}{ Clay loam } \\
\hline & OMF & MAP & OMF & MAP & OMF & MAP & OMF & MAP \\
\hline 50 & $1.14 \mathrm{a}$ & $0.99 \mathrm{a}$ & $0.94 \mathrm{~b}$ & $0.65 \mathrm{c}$ & $1.15 \mathrm{a}$ & $1.06 \mathrm{a}$ & $0.70 \mathrm{~b}$ & $0.61 \mathrm{~b}$ \\
\hline 100 & $0.74 \mathrm{a}$ & $0.63 \mathrm{ab}$ & $0.65 \mathrm{a}$ & $0.51 b$ & $1.09 \mathrm{a}$ & $1.28 \mathrm{a}$ & $0.47 b$ & $0.38 \mathrm{~b}$ \\
\hline 200 & $0.41 \mathrm{a}$ & $0.39 \mathrm{a}$ & $0.41 \mathrm{a}$ & $0.37 \mathrm{a}$ & $0.80 \mathrm{a}$ & $0.92 \mathrm{a}$ & $0.40 \mathrm{~b}$ & $0.32 b$ \\
\hline 400 & $0.21 \mathrm{a}$ & $0.15 \mathrm{a}$ & $0.24 \mathrm{a}$ & $0.21 \mathrm{a}$ & $0.74 \mathrm{a}$ & $0.63 \mathrm{a}$ & $0.36 \mathrm{~b}$ & $0.32 b$ \\
\hline Mean & $0.62 \mathrm{a}$ & $0.54 \mathrm{~b}$ & $0.56 \mathrm{ab}$ & $0.43 c$ & $0.94 \mathrm{a}$ & $0.97 \mathrm{a}$ & $0.48 b$ & $0.41 \mathrm{~b}$ \\
\hline
\end{tabular}

${ }^{(1)}$ Means followed by equal letters, in the rows, do not differ significantly by Duncan's test, at $5 \%$ probability. 
soluble mineral fertilizer allows the partial replacement of the mineral fertilizer in large-scale plantations, particularly in regions near poultry farms. This strategy allows the diversification and decentralization of fertilizer production in Brazil (Benites et al., 2010) and may optimize the use of raw materials in the farm. In addition, the use of agro-industrial waste in the production of OMFs may minimize the negative environmental impacts caused by the inadequate disposal of these wastes and reduce the use of mineral fertilizers in agriculture. It should also be noted that this strategy is more sustainable for the management of soil fertility (Liu et al., 2009).

\section{Conclusions}

1. Fertilization with granulated organomineral phosphate fertilizer (OMF) from poultry litter has a greater immediate effect than that with monoammonium phosphate (MAP), with higher accumulation of dry matter by corn (Zea mays) plants in the first cultivation.

2. At the evaluated doses, residual effects do not significantly differ between $\mathrm{P}$ sources, and the accumulation of dry matter by plants is similar in the subsequent cultivations.

3. The sources of $P$ show the same $P$ recovery efficiency, which, combined with the higher dry matter production with OMF, results in a greater agronomic efficiency of this P source, compared with MAP.

\section{Acknowledgments}

To the postgraduate course in agronomy and soil science of Universidade Federal Rural do Rio de Janeiro (UFRRJ); and to Embrapa Solos, to Embrapa Agrobiologia, to Embrapa/Rede Fertbrasil, and to Conselho Nacional de Desenvolvimento Científico e Tecnológico (CNPq), for technical and financial support.

\section{References}

BENITES, V. de M.; CORREA, J.C.; MENEZES, J.F.S.; POLIDORO, J.C. Produção de fertilizante organomineral granulado a partir de dejetos de suínos e aves no Brasil. In: REUNIÃO BRASILEIRA DE FERTILIDADE DO SOLO E NUTRIÇÃO DE PLANTAS, 29; REUNIÃO BRASILEIRA SOBRE MICORRIZA, 13.; SIMPÓSIO BRASILEIRO DE MICROBIOLOGIA DO SOLO, 11; REUNIÃO BRASILEIRA DE BIOLOGIA DO SOLO, 8., 2010, Guarapari. Fontes de nutrientes e produção agrícola: modelando o futuro: anais. Viçosa: SBCS, 2010.

BHATTACHARYYA, R.; KUNDU, S.; PRAKASH, V.; GUPTA, H.S. Sustainability under combined application of mineral and organic fertilizers in a rainfed soybean-wheat system of the Indian Himalayas. European Journal of Agronomy, v.28, p.3346, 2008. DOI: 10.1016/j.eja.2007.04.006.

BRASIL. Lei $\mathrm{n}^{\circ}$ 12.305, de 2 de agosto de 2010. Institui a Política Nacional de Resíduos Sólidos; altera a Lei $\mathrm{n}^{\circ}$ 9.605, de 12 de fevereiro de 1998 e dá outras providências. Diário Oficial da União, 3 ago. 2010. Seção 1, p.2-7.

CHIEN, S.H.; PROCHNOW, L.I.; TU, S.; SNYDER, C.S. Agronomic and environmental aspects of phosphate fertilizers varying in source and solubility: an update review. Nutrient Cycling Agroecosystems, v.89, p.229-255, 2011. DOI: 10.1007/ s10705-010-9390-4.

CLAESSEN, M.E.C. (Org.). Manual de métodos de análise de solo. 2.ed. rev. e atual. Rio de Janeiro: Embrapa-CNPS, 1997. 212p. (Embrapa-CNPS. Documentos, 1).

CORDELL, D.; DRANGERT, J.O; WHITE, S. The story of phosphorus: global food security and food for thought. Global Environmental Change, v.19, p.292-305, 2009. DOI: 10.1016/j. gloenvcha.2008.10.009.

FAGERIA, N.K.; SLATON, N.A.; BALIGAR, V.C. Nutrient management for improving lowland rice productivity and sustainability. Advances in Agronomy, v.80, p.63-152, 2003. DOI: $10.1016 / \mathrm{S} 0065-2113(03) 80003-2$.

FERNANDES, D.M.; GROHSKOPF, M.A.; GOMES, E.R.; FERREIRA, N.R.; BÜLL, L.T. Fósforo na solução do solo em resposta à aplicação de fertilizantes fluidos mineral e organomineral. Irriga, v.1, p.14-27, 2015. Edição Especial 20 anos Irriga +50 anos FCA. DOI: 10.15809/irriga.2015v1n1p14.

FERREIRA, N.R. Eficiência agronômica de fertilizantes organominerais sólidos e fluidos em relação à disponibilidade de fósforo. 2014. 67p. Dissertação (Mestrado) - Universidade Estadual Paulista Júlio de Mesquita, Botucatu.

GATIBONI, L.C.; KAMINSKI, J.; RHEINHEIMER, D. dos S.; BRUNETTO, G. Fósforo da biomassa microbiana e atividade de fosfatases ácidas durante a diminuição do fósforo disponível no solo. Pesquisa Agropecuária Brasileira, v.43, p.1085-1091, 2008. DOI: 10.1590/S0100-204X2008000800019.

HANSEL, F.D.; AMADO, T.J.C.; BORTOLOTTO, R.P.; TRINDADE, B.S.; HANSEL, D.S.S. Influence of different phosphorus sources on fertilization efficiency. Applied Research and Agrotecnology, v.7, p.103-111, 2014. DOI: 10.5935/PAeT. V7.N1.12.

IBGE. Instituto Brasileiro de Geografia e Estatística. Indicadores IBGE: estatística da produção pecuária: março de 2016. 2016. 76p. Available at: <http://biblioteca.ibge.gov.br/visualizacao/ periodicos/2380/epp_2016_mar.pdf >. Accessed on: June 242016.

KIEHL, E.J. Fertilizantes organominerais. 2.ed. Piracicaba: Degaspari, 2008. 160p.

KOCHIAN, L.V. Rooting for more phosphorus. Nature, v.488, p.466-467, 2012. DOI: 10.1038/488466a. 
LANA, M. do C.; RAMPIM, L.; SCHULZ, L.R.; KAEFER, J.E.; HARTMANN-SCHMIDT, M.A.; RUPPENTHAL, V. Disponibilidade de fósforo para plantas de milho cultivadas com fertilizante organomineral e fosfato monoamônico. Scientia Agraria Paranaensis, v.13, p.198-209, 2014. DOI: 10.18188/19831471/sap.v13n3p198-209.

LIU, M.; HU, F.; CHEN, X.; HUANG, Q.; JIAO, J.; ZHANG, B.; LI, H. Organic amendments with reduced chemical fertilizer promote soil microbial development and nutrient availability in a subtropical paddy field: the influence of quantity, type and application time of organic amendments. Applied Soil Ecology, v.42, p.166-175, 2009. DOI: 10.1016/j.apsoil.2009.03.006.

MALAVOLTA, E.; VITTI, G.C.; OLIVEIRA, S.A. de. Avaliação do estado nutricional das plantas: princípios e aplicações. 2.ed. Piracicaba: Associação Brasileira para Pesquisa da Potassa e do Fosfato, 1997. 319p.

MORAIS, F.A.; GATIBONI, L.C. Phosphorus availability and microbial immobilization in a Nitisol with the application of mineral and organo-mineral fertilizers. Anais da Academia Brasileira de Ciências, v.87, p.2289-2299, 2015. DOI: 10.1590/0001-3765201520140008.

RODRIGUES, P.N.F.; ROLIM, M.M.; BEZERRA NETO, E.; COSTA, R.N.T.; PEDROSA, E.M.R.; OLIVEIRA, V.S. Efeito do composto orgânico e compactação do solo no milho e nutrientes do solo. Revista Brasileira de Engenharia Agrícola e Ambiental, v.15, p.788-793, 2011. DOI: 10.1590/S141543662011000800004.

ROSOLEM, C.A.; ASSIS, J.S.; SANTIAGO, A.D. Root growth and mineral nutrition of corn hybrids as affected by phosphorus and lime. Communications in Soil Science and Plant Analysis, v.25 p.2491-2499, 1994. DOI: 10.1080/00103629409369202.

SANTOS, D.H.; SILVA, M. de A.; TIRITAN, C.S.; FOLONI, J.S.S.; ECHER, F.R. Qualidade tecnológica da cana-de-açúcar sob adubação com torta de filtro enriquecida com fosfato solúvel. Revista Brasileira de Engenharia Agrícola e Ambiental, v.15, p.443-449, 2011. DOI: 10.1590/S1415-43662011000500002.

SANTOS, H.G. dos; JACOMINE, P.K.T.; ANJOS, L.H.C. dos; OLIVEIRA, V.A. de; LUMBRERAS, J.F.; COELHO, M.R.; ALMEIDA, J.A. de; CUNHA, T.J.F.; OLIVEIRA, J.B. de. Sistema Brasileiro de Classificação de Solos. 3.ed. rev. e ampl. Brasília: Embrapa, 2013.

SCHNEIDER, V.E.; PERESIN, D.; TRENTIN, A.C.; BORTOLIN, T.A.; SAMBUICHI, R.H.R. Diagnóstico dos resíduos orgânicos do setor agrossilvopastoril e agroindústrias associadas: relatório de pesquisa. Brasília: Ipea, 2012. 129p.

SCIVITTARO, W.B.; BOARETTO, A.E.; MURAOKA, T. Eficiência agronômica de fertilizantes fosfatados fluidos e sólidos. Revista Brasileira de Ciência do Solo, v.21, p.505-511, 1997. DOI: $10.1590 / \mathrm{S} 0100-06831997000300021$.

SILVA, A. de A.; COSTA, A.M. da; LANA, R.M.Q.; LANA, A.M.Q. Recycling of nutrients with application of organic waste in degraded pasture. Engenharia Agrícola, v.32, p.405-414, 2012. DOI: 10.1590/S0100-69162012000200020.

VACCARI, D.A. Phosphorus: a looming crisis. Scientific American, v.300, p.54-59, 2009. DOI: 10.1038/ scientificamerican0609-54.

Received on September 25, 2016 and accepted on February 16, 2017 